\title{
Detection of lasB Gene of Pseudomonasaeruginosa Causing Different Infection
}

\author{
Rana M. Abdullah Al-Shwaikh ${ }^{1 *}$ and Abbas Falih Al-Arnawtee \\ ${ }^{1}$ Department of Biology, College of Education Ibn-Al Haitham, University of Baghdad. \\ *Corresponding Author: dr.rana_alshwaikh@yahoo.com
}

\begin{abstract}
The result obtained 75 isolate of Pseudomonasaeruginosa included: 28 isolates from otitis media, 23 isolates from burn infections, 10 isolates from wound infections, 8 isolates from urinary tract infections and 6 isolates from blood. The isolates were identified by culturing on MacConkey agar, Blood agar, Cetrimide agar, Pseudomonas agar and CHROMagar Orientation then identified by performing biochemical tests including (oxidase test and catalase test) and further identification by using a API20E system. The result obtained Pseudomonasaeruginosa that have Las B included : 23 isolates from otitis media 82.14\%, 19 isolates from burn infections 82.60\%,10 isolates from wound infections $100 \%, 5$ isolates from urinary tract infections $62.5 \%$ and 6 isolates from blood $100 \%$. The result revealed that the lasB gene was present in 63 isolates $84 \%$ of Pseudomonasaeruginosa. The gel electrophoresis showed that the molecular weight of alg $D$ gene was 300bp. [DOI: 10.22401/ANJS.00.2.07]

Conclusions: The results of the detection the virulence gene showed that Pseudomonasaeruginosa have las $B$ gene $84 \%$ that encoded elastase enzyme as the enzyme is highly efficient in protein analysis and the necrosis process.
\end{abstract}

Key words: Pseudomonasaeruginosa, Las Bgene.

\section{Introduction}

$P$. aeruginosa produces a variety of enzymes such as Alkaline Protease and Elastase, Alkaline Protease combines with Elastase to analyze Collagen and Elastin [1]. When the enzyme secretion in large quantities, necrosis occurs in the injury zone Especially in the case of lung infections in patients with cystic fibrosis, which leads to the destruction of epithelial cells [2] and has the ability to analyze soft tissue and many molecular biologics effective such as Fibrinogen [3] and Components of the Complementary System [4]. Proteases Enzymes also have an important role in increasing the virulence of P.aeruginosa bacteria especially when their extracellular secretion is important in destroying host tissues [5].

Elastase is one of the main virulence factors of P.aeruginosa and is associated with severe tissue damage during the invasion of the tissue by the bacteria [6]. Its virulence lies in its ability to break Elastin, a protein that is an important component. Elastase has an important role in determining the virulence of P.aeruginosa during the time of infection [7]. Proteases have different molecular weights from 20-60 $\mathrm{kDa}$, most of which are extracellular. P.aeruginosa produce many proteases, and these proteins was Protease IV have a molecular weight of $26 \mathrm{kDa}$. As well as the type alkaline protease, which is the type of metallic extrusion cellular [8]. As well as Las A protease, which is also extracellular, molecular weight (20) $\mathrm{kDa}$ and elastase with a molecular weight of $33 \mathrm{kDa}$ [9].

The elastase enzyme is encoded by las $B$ gene, as the enzyme Las B elastase is highly efficient in protein analysis and the necrosis processes [10]. The process controlling by las $B$ gene is performed during the QuorumSensing Transcription process [11].

The aim of this study is to detect Las $B$ virulence genes by using PCR techniques.

\section{Materials and method}

1. Collection of bacteria: Bacteria were collected from different infection cases including burin and wound infection, otitis media, urinary tract infection and blood samples.

2. Identification of bacteria: identification of the isolates by culturing on media culture including MacConkey agar, Blood agar, Cetrimide agar, Pseudomonas agar and CHROMagar Orientation then identified by using biochemical tests 
including (oxidase and catalase test) and further identification by using a API20E system [12].

3.DNA isolation: DNA kit was used for extracting DNA of bacterial for isolates (Geneaid Biotech kit system, UK) according to the manufacturer's instructions.

4. Detection of las $B$ gene: To determine las $B$ gene of P.aeruginosa isolates by using the primer lasB $300 \mathrm{bpF}$ :
(GGAATGAACGAAGCGTTCTC), R: (GGTCCAGTAGTAGCGGTTGG).

Detection of the gene las $B$ attended the solution concentration of 10 pekmole/ $\mu \mathrm{l}$ (by taking $10 \mu \mathrm{l}$ from Stock solution and addition of $90 \mu \mathrm{l}$ of distilled water Alloaona) The Stock solution was saved under $-20{ }^{\circ} \mathrm{C}$. Polymerase chain PCR interactive and conditions were described below [13].

\begin{tabular}{|c|c|c||}
\hline Step & \multicolumn{2}{|c||}{ Program } \\
\hline \hline \multirow{2}{*}{1} & \multicolumn{2}{|c|}{ Initial denaturation at $94^{\circ} \mathrm{C}$ for 3 min 1 cycle } \\
\hline \multirow{2}{*}{2} & \multicolumn{2}{|c|}{30 cycles } \\
\cline { 2 - 3 } & $\mathrm{A}$ & Denaturation DNA template at $94^{\circ} \mathrm{C}$ for $30 \mathrm{sec}$. \\
\cline { 2 - 3 } & $\mathrm{B}$ & Annealing at $55^{\circ} \mathrm{C}$ for $1 \mathrm{~min}$ \\
\cline { 2 - 3 } & $\mathrm{C}$ & Extension at $72^{\circ} \mathrm{C}$ for 1 min. \\
\hline 3 & \multicolumn{2}{|c|}{ A final extension at $72^{\circ} \mathrm{C}$ for 5 min 1 cycle } \\
\hline \hline
\end{tabular}

5. Separation of DNA bands: PCR products were separated on a $2 \%$ agarose with $5 \mu \mathrm{l}$ Ethidium bromide Bio Basic INC (Canada), at 50 vol. for $2 \mathrm{hrs}$, using $100 \mathrm{bp}$ Ladder. The DNA bands were visualized and photographed under UV light Optima (Japan) [14].

\section{Results and discussion}

A total of 75 isolates of P.aeruginosa were isolated including : 28 isolates from otitis media, 23 isolates from burn infections, 10 isolates from wound infections, 8 isolates from urinary tract infections and 6 isolates from blood. The isolates were identified by culturing on MacConkey agar, Blood agar, Cetrimide agar, Pseudomonas agar and CHROMagar Orientation then identified by performing biochemical tests including oxidase and catalase test and further identified by using a API20E system as shown in table (1).

Table (1)

Preliminary diagnostic test results for Pseudomonas aeruginosa.

\begin{tabular}{|c|c|c||}
\hline No. & Test & Result \\
\hline \hline 1 & Gram stain & -ve Rods \\
\hline 2 & MaConkey agar & non-Lactose fermented \\
\hline 3 & Blood agar & -haemolytic \\
\hline 4 & Cetrimide agar & Green or creamy green \\
\hline 6 & Pseudomonas agar & Green or creamy green \\
\hline 7 & CHROM agar Orientation & + \\
\hline 8 & Catalase test & + \\
\hline 9 & Oxidase test & \\
\hline
\end{tabular}


Result revealed that the lasB gene was present in 63 isolates (84\%) of P.aeruginosa. Pseudomonasaeruginosa have LasB included: 23 isolates from otitis media $(\mathbf{8 2 . 1 4 \%}), 19$ isolates from burn infections $(\mathbf{8 2 . 6 0 \%}), 10$ isolates from wound infections $(100 \%), 5$ isolates from urinary tract infections $(\mathbf{6 2 . 5 \%})$ and 6 isolates from blood (100\%) as shown in table (2). The gel electrophoresis showed that the molecular weight of lasB gene was 300 bp. (Figure1).

Table (2)

Number and percentage of las $B$ gene of $P$. aeruginosa.

\begin{tabular}{|c|c|c|c||}
\hline \hline No. & Sources & No. & lasB(\%) \\
\hline \hline 1 & Otitis media & 23 & $(82.14)$ \\
\hline 2 & Burn & 19 & $(82.60)$ \\
\hline 3 & Wound & 10 & $(100)$ \\
\hline 4 & UTI & 5 & $(62)($. \\
\hline 5 & Blood & 6 & $(100)$ \\
\hline \multicolumn{2}{|c|}{} \\
\hline
\end{tabular}

This study was similar with this carried out by Wolska and Szweda (2009) [15] who showed $84.6 \%$ of the isolated $P$. aeruginosa have lasB, and agree with Shi et al. (2012) [16] who found that $80 \%$ of $P$. aeruginosa have lasB, Sabharwalet al. (2014) [17] found that $75 \%$ of $P$. aeruginosaisolates confer this gene.

The results showed that a high proportion of clinical isolates possessed the las $B$ gene because it encodes the production of the enzyme elastase [10], which is an important virulence factor that helps $P$. aeruginosa to break down Elastin protein. This protein is an important component for human blood vessels and responsible for its elasticity. Elastin is also a major constituent of lungs, responsible for the process of lung expansion and contraction. Therefore, the enzyme Elastase plays an important role in determining the virulence of P.aeruginosa during the infection [7].

M 57585960616263646566676869707172737475

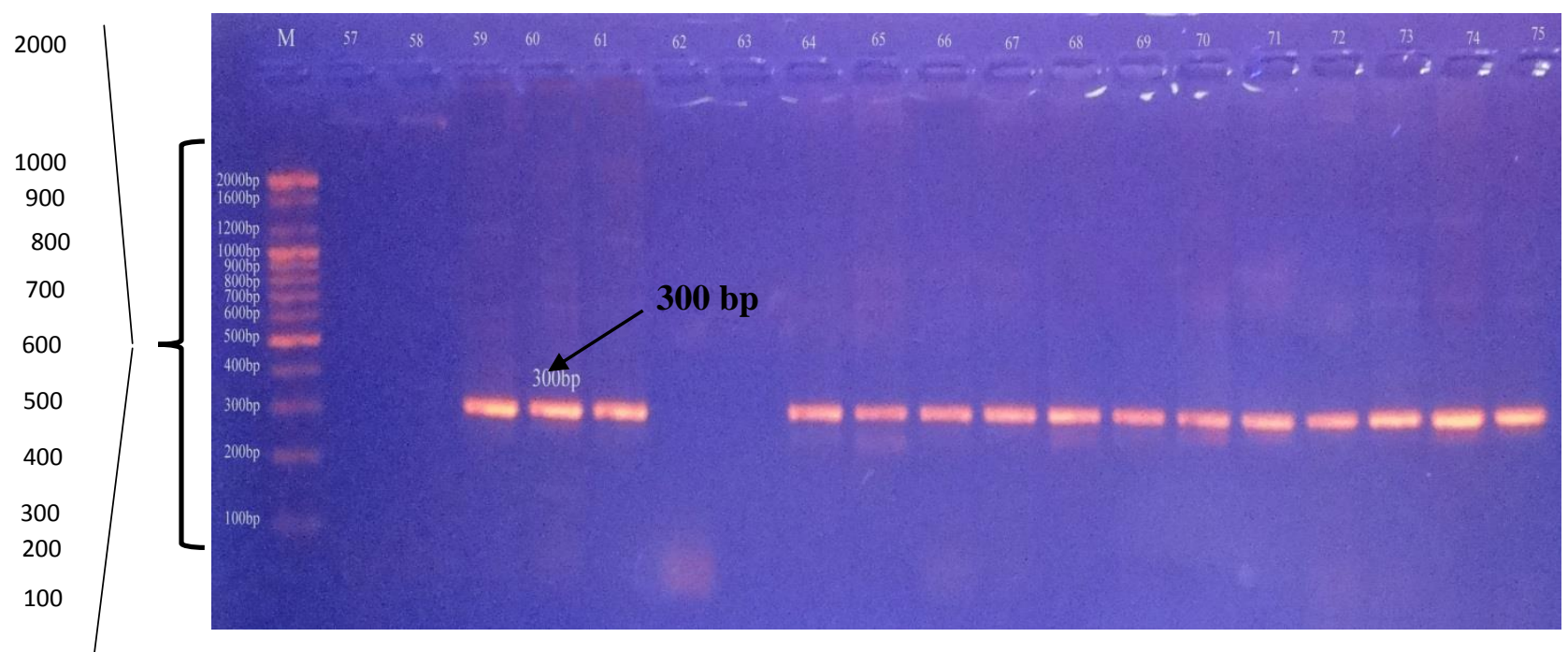

Figure (1) Agarose gel electrophoresis (2\%) of PCR products of las B gene (300 bp). Line M: DNA marker (100 bp-2000 bp ladder, Promega, USA); Lanes 57-75 Pseudomonasaeruginosa PCR-positive isolates. 


\section{Conclusions:}

The results of the detection the virulence gene showed that Pseudomonasaeruginosa have lasB gene (84\%) that encoded elastase enzyme as the enzyme is highly efficient in protein analysis and the necrosis process.

\section{Reference}

1. Ulrich M., Worlitzsch D., Viglio S., Siegmann N., Iadarola P., Shute J. K., Geiser M., Pier, G. B., Friede G., Barr M. L., Schuster A., Meyer K. C., Ratjen F., Bjarnsholt T., Gulbins E., Doring G., Alveolar inflammation in cystic fibrosis. J. Cyst. Fibrosis. 9(3): 217-227. 2010.

2. Parker D., Cohen T.S., Alhede M., Harfenist B.S., Martin F.J. and Prince A. Induction of type I interferon signaling by Pseudomonasaeruginosa is diminished in cystic fibrosis epithelial cells. AM. J. Respir. Cell Mol. Biol. 46(1): 6-13. 2012.

3. Komori Y., Nonogaki T. and Nikai T. Hemorrhagic activity and muscle damaging effect of Pseudomonas aeruginosametallo proteinase (elastase). J. Toxicon. 39(9): 1327-1332. 2001.

4. Laarman A.J., Bardoel B.W., Ruyken M., Fernie J., Milder F.J., Strijp J.A.G. and Rooijakkers S.H.M. Pseudomonas aeruginosa alkaline protease blocks complement activation via the classical and lectin pathways. J. Immunology. 188: 386-393. 2015.

5. Seo L. Darwin A.J. The Pseudomonas aeruginosa periplasmic protease Ctp A can affect system that impact its ability to mount both acute and chronic infections. J. ASM. 81(12): 4561-4570. 2013.

6. Hoge R., Pelzer A. Rosenau F. and Wilhelm S. Weapons of a pathogen: proteases and their role in virulence of Pseudomonasaeruginosa. J. Microbial Biotechnology. 1: 3 83-395. 2010.

7. Bai F., Xu H., Zhang Q., Qi X., Mou R., Bai G. and Qiao M. Functional characterization of $\mathrm{pfm}$ in protein secretion and lung infection of Pseudomonas aeruginosa. Can. J. Microbiol. 57: 829-837. 2011.

8. Jewell S. N. Purification and characterization of a novel protease from
Burkholderia strain 2.2 N. MSC. Thesis. Virginia Polytechnic Institute and State University. Blacksbury, Virginia.2000.

9. GustinJ. K.,Kessler E. and Ohman D.E. Asubstitution at His-120 in the Las A protease of Pseudomonas aeruginosa blocks enzymatic activity without affecting propeptide processing or extracellular secretion. J. Bacteriol. 178 (22): 6608-6617. 1996.

10. Cathcart G.R.A., Quinn D., Greer B., HarriottP., Lynas J.F., Gilmore B.F. and Walker B. Novel inhibition of the Pseudomonas aeruginosa virulence factor Las B : a potential therapeutic approach for the attenuation of virulence mechanisms in Pseudomonal. Antimicrob Agents Chemother. J. Microbiology. 55(6): 2670-2678. 2011.

11. Zhao K., Li Y., Yue B. and $\mathrm{Wu} \mathrm{M}$. Genes as early responders regulate quorum sensing and control bacterial cooperation in Pseudomonas aeruginosa. PLOSone. 9(7): e101887.2014.

12. Baron E. J., Finegold S. M. and Peterson I. L. R. Bailey and Scott،s Diagnostic Microbiology. 9th ed. Mosby Company. Missouri. 2007.

13. Sonbol F., Khalil M.A.E., Mohamed A.B. and Ali S.S. Correlation between antibiotic resistance and virulence of Pseudomonas aeruginosa clinical isolates. Turkish J. Medical Sciences. 45: 1406-1458. 2015.

14. Sambrook J. and Rusell D. W. Molecular cloning a laboratory manual. Cold spring Harbor, NY: cold spring Harbor Laboratory press. 2001.

15. Wolska K. and Szweda P. Genetic features of clinical Pseudomonas aeruginosa strains. J. Microbiology. 58(3): 255-260. 2009.

16. Shi H., Sun F., Chen J., Ou Q., Feng W., Yong X. and Xia P. Epidemiology of CTX-M-type extended-spectrum $\beta$ lactamase (ESBL)-producing nosocomial Escherichia coli infection in china. Annals Clinical Microbiology Antimicrobials. 14: 1-4. 2015.

17. Sabharwal N., DhallS., Chhibber S. and Harjai K. Molecular detection of virulence genes as markers in 
Special Issus: $1^{\text {st }}$ Scientific International Conference, College of Science, Al-Nahrain University, 21-22/11/2017, Part II, pp.48-52

Pseudomonas aeruginosa isolated from urinary tract infections. Int. J. Mol. Epidemiol Genet. 5(3): 125-134. 2014. 